\title{
アトマイズ鋳鉄粗粉末のパルス通電加压焼結の 初期過程におけるネック成長
}

\author{
南口＼cjkstart誠* 丸山俊夫* 冨野寿和**
}

\author{
*東京工業大学工学部金属工学科 \\ **香川県工業技術センター
}

J. Japan Inst. Metals, Vol. 63, No. 7 (1999), pp. 917-923

\section{Neck Growth on Initial Stage of Pulse Current Pressure Sintering for Coarse Atomized Powder Made of Cast-Iron}

\author{
Makoto Nanko*, Toshio Maruyama* and Hisakazu Tomino** \\ *Department of Metallurgical Engineering, Faculty of Engineering, Tokyo Institute of Technology, \\ Tokyo 152-8552 \\ ** Kagawa Industrial Technology Center, Takamatsu 761-8031
}

\begin{abstract}
Sample temperature and neck growth were investigated on pulse-current pressure sintering of coarse castiron powder (diameter: $200 \mu \mathrm{m}$ ) produced by a gas atomizing technique. At $873 \mathrm{~K}$ of die temperature, the temperatures of sample inside and its surface were $950 \mathrm{~K}$ and $910 \mathrm{~K}$, respectively. Microstructure observation of the sintered cast-iron revealed that there were no melting and remarkable deformation around the grain interface. Neck growth was governed by plastic deformation during the initial stage of the process. A model calculation of neck growth by assuming the plastic deformation of particles is in good agreement with the experimental results. The results indicate that the initial stage on pulse current pressure sintering is similar to conventional hot-press sintering for coarse cast-iron powder.
\end{abstract}

(Received December, 11, 1998; In Final Form March 29, 1999)

Keywords: pulse-current pressure sintering, spark plasma sintering (SPS), neck growth, plastic deformation, cast-iron powder, samle temperature

\section{I . 緒言}

最近，プラズマ活性化焼結(PAS)や放電プラズマ焼結 (SPS) が急速焼結法として，様々な分野で注目されてい る(1)-(6).これらの方法は試料を入れた導電性の型を通電加 熱し，加圧焼結を行うものである.これらの焼結方法は従来 の通電焼結とは異なり, 低電圧, 高電流のもとで行われ, 投 入される電力量も小さい，また，PAS 法ではプロセスの初 期に直流パルス電流を, SPS 法では全プロセスにわたって 直流パルス電流を印加することより通電焼結を行らため, 総 称してパルス通電焼結法と呼ばれている(7)。ここでは一軸加 圧の下で焼結が行われることが重要であると考えて，パス 通電加圧暁結と呼ぶこととする.

パルス通電加圧焼結中に起きる現象については様々な議論 がなされている、これまでは，パス通電によるネック付近 での放電や著しいジュール発熱のため, 粒子接合部(ホック)

† 1998年 3 月日本金属学会春期大会に抹いて発表
近傍での局部的な融解や気化が起き，急速に焼結が進行する と説明されている(1)。しかし，このような覞結機構は実験的 に確認されていない。最近, その焼結機構の解明を目的とし て，通電による金属粒子成形体の電気抵抗(8)や型扣よび試料 の温度分布 ${ }^{(9)}$-(11)，㐫るい:金属粒子の接合形態 ${ }^{(12)-(14) や ア ~}$

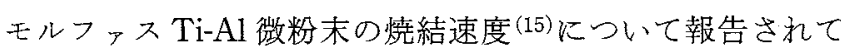
いる.

パルス通電加生暁結では粉末を成形する型の表面温度によ って焼結プロセスを制御する，そのため，パス通電加压燒 結の焼結現象を議論するためには, 試料内部の温度を正確に 知る必要がある。富野ら ${ }^{(9)}$ は外径 $70 \mathrm{~mm}$, 内径 $20 \mathrm{~mm}$ の黒 鉛型拉よび試料内部に熱電対を挿入し，銅とアルミナに関し て SPS 焼結中の試料内部の温度を測定した。その結果，銅 を試料とした場合は型表面温度 $950 \mathrm{~K}$ に対して試料中央の 温度は $180 \mathrm{~K}$ 高い $1130 \mathrm{~K}$ に達して和り，また，型/試料界 面は型表面よりも $110 \mathrm{~K}$ 高い $1060 \mathrm{~K}$ としている. 一方, 試 料がアルミナの場合は, 型表面が $970 \mathrm{~K} に$ 沶いて試料中央 部は $1070 \mathrm{~K}$ ，型試料界面は $1030 \mathrm{~K}$ に達する。をた，阿部 ら (10)はパルス通電加压焼結した鉄焼結体の超音波映像の結 
果から, 試料の焼結温度は表面より内部が $50 \mathrm{~K}$ ほど高いこ とを見出した，䳺見ら (11) 虹外径 $50 \mathrm{~mm}$ ，内径 $30 \mathrm{~mm}$ の黒鉊 型にSUS304，黑鉛，アルミナの緻密体を試料として捙入 し，制御温度を表面加 $3 \mathrm{~mm}$ の深さの型壁内部の温度と し，型および試料の内部温度を熱電対により測定した。制御 温度 $1025 \mathrm{~K}$ K和いて SUS304 では型/試料界面で $1090 \mathrm{~K}$, 試料中央で $1175 \mathrm{~K}$ であった。黒鉛では制御温度 $1029 \mathrm{~K}$ K 扣いて型/試料界面で $1110 \mathrm{~K}$ ，試料中央で $1200 \mathrm{~K}$ となっ た。またアルミナの場合は制御温度 $1022 \mathrm{~K}$ に扣いて型/試 料界面では $1180 \mathrm{~K}$ に達したが，試料中央部は $980 \mathrm{~K}$ となり 制御温度を下回っていた。むた，鶋見ら(11)は実験結果と熱 伝尊の解析から導電性試料では試料内部と型の内側表面が, 絶縁性試料では型の内側表面のみが発熱源であると報告して いる。このよらに，型と試料内部の温度がかなり異なり，そ の違いは型の寸法や試料の材質, 墝結温度などに大きく左右 される，パルス通電焼結加圧焼結の燒結挙動の検討には試料 温度の実測が必要不可欠である。

パス通電加圧焼結の焼結挙動に関してはいくつかの検討 がなされてる。林と小林 ${ }^{(15)}$ は試料内部の温度を測定した 上で Ti-Al 系のアモルファス微粉末の焼結速度を測定した。 彼らは，焼結速度から計算した粘性流動の見かけの活性化工 ネルギが投入電厈量の増加によって減少したと報告してい る。横田ら ${ }^{(12)}$ と長柄ら ${ }^{(13)}$ はS SPS法によりがスアトマイズ Al-Si 合金を焼結し，その組織観察を行った。ネック付近の 粒子表面に部分的な融解の痕跡が認められた (12). 不，粒 子の接合界面の組織からネックの形成が粒子の塑性変形であ ることを示唆している(13)。ささらに，冨野ら(14)はガスアトマ イズ法で作製した鋳鉄粉末をSPS法により焼結した。彼ら は，試料から $1 \mathrm{~mm}$ の深さまで型内に熱電対を挿入し，焼 結用の制御温度とした。ネック表面の曲率半径が極めて小さ く, 制御温度 $973 \mathrm{~K}$ 以下ではネック部に粒子間の境界が確 認された。また，その際，粒子内部と境界付近での組織は明 確な違いが観察されなかった。以上のことから，パルス通電 加圧槙結による鋳鉄粒子のネック成長は粒子の塑性変形によ ると結論している。

金属粉末のパルス通電加圧焼結は，組織観察の結果から粒 子の塑性変形が支配的な要因であると考觉られる。しかし， 焼結挙動の速度論的な考察は汪とんど行わ机ていない。パル 又通電加圧焼結の焼結機構を明らかにするためには定量的な 焼結速度の解析が非常に有効である。

パルス通電加王焼結に拈いてネック近傍での放電や局部的 なジュール発熱が起きるとすれば，粒子の接触時からネック がある程度の大ささになるまでの焼結の初期過程が最も影響 されると考觉られる。したがって，パルス通電加圧の下で粒 径が大きい粉末を熍結した場合，ネック部近傍とそれ以外の ところでは組織が大きく異なると考えられる。

白鋳鉄は高機能ダイヤモンド研削砥石のボンド材として注 目されて扣り (14)(15)-(19)，その焼結方法として，SPS法が検 討されている(14)(18)(19)，そこで本研究は試料の内部温度を
測定した上で，ガスアトマイズ法で作製した鋳鉄粗粉末のパ ルス通電加圧焼結の初期過程に执けるネック部の微細組織を 観察し，ネック成長速度を定量的に検討した。鋳鉄アトマイ ズ粉末以融体から急激に冷却されて粉末になるので，粒子は 球形であり，Fe-C系共晶組織学有する白鋳鉄から構成され る。この粉末を用いることで，粒子の変形やネックの大さ さ，接合形態を容易に観察でさる。交た，焼結による微細組 織の変化から焼結時の試料温度の推定が可能である。

\section{II. 実 験 方 法}

鋳鉄粉末はガスアトマイズ法により作製されたもので，炭 素量は 4 mass\%である。年の粉末をふるい\#70/\#83 Kよ り分級し，試料粉末とした。Fig. 1 火実験に用いたアトマ イズ鋳鉄粉末の走查型電子影微鏡(SEM) 写真を示す．粉末 粒子は球状であり，粒径が $200 \mu \mathrm{m}$ 程度で均一であった。試 料粉末は共晶組成に非常に近い重共晶領域にあるので, 微細 組織は臣とんどが Fe-C 系共晶系特有のレデブライト組織 $(\gamma$ $\mathrm{Fe}$ と $\mathrm{Fe}_{3} \mathrm{C}$ )からなって蛙り，一部， $\gamma$ - $\mathrm{Fe}$ の初晶によるデン
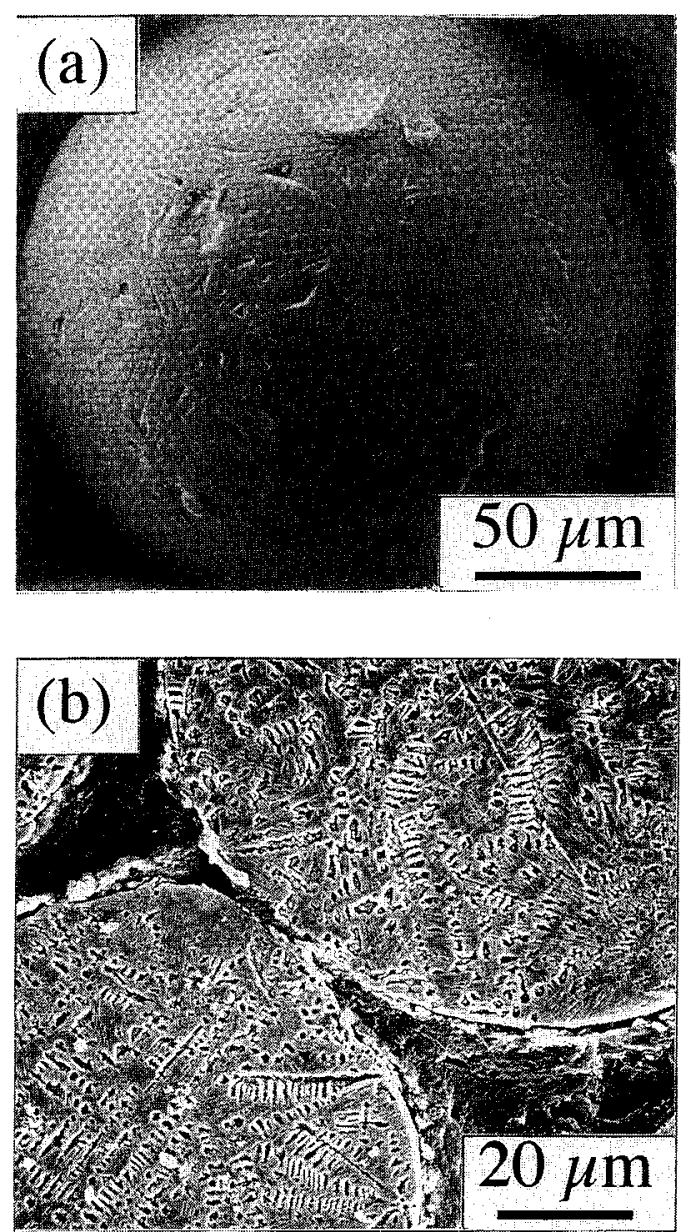

Fig. 1 SEM images of atomized cast-iron. (a) particle surface, and (b) cross-section after etching. 
ドライトが観察される。X 線回折の結果, 試料粉末は主に $\alpha-\mathrm{Fe}$ と $\mathrm{Fe}_{3} \mathrm{C}$ からり，微量の残留オーステナイト $(\gamma-\mathrm{Fe})$ と $\mathrm{FeO}$ が確認された。

焼結装置は住友石炭鉱業侏製放電プラズマ焼結機 (Dr. Sinter Lab. Model: SPS-510A)を用いた。外径 $30 \mathrm{~mm}$ ，内径 $15.4 \mathrm{~mm}$, 高さ $40 \mathrm{~mm}$ の黒鉛製型の内面にカーボンペーパ 一を巻さ，その中に鋳鉄粉末を入れた。また，パンチと試料 の間にもカーボンペーパーを挿入した。焼結実験に先立ち， 黒鉛型内の試料温度を測定した. Fig. 2 にとの模式図を示 す， K 熱電対(アルメルークロメル)を，ムライト保護管と アルミナセメントルより絶縁し，パンチ中に埋め込んだ。試 料温度测定用の試料として，錆鉄粉末とその焼結体(相対密

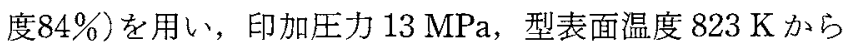
$1023 \mathrm{~K}$ に和いて試料/パンチ界面と試料表面から約 $3 \mathrm{~mm}$ の 深さの試料内部の温度を測定した。ささらに，粉末試料を用い て, 試料表面もしくは試料内部の温度のみを測定し，熱電対 を挿入したパンチを用いた影響を検討した。

焼結実験は型表面温度 $873 \mathrm{~K}$ 真空下で行った。印加圧力 は $13 \mathrm{MPa}$ と $34 \mathrm{MPa}$ とし，保持時間は 0 から $1.8 \mathrm{ks}$ とし た。昇温開始前に粉末を加生し， $823 \mathrm{~K}$ まで $480 \mathrm{~s}$ ，その 後, $873 \mathrm{~K}$ まで $120 \mathrm{~s}$ で昇温させた。温度保持終了後, 速や か以印加圧力を除去し，真空のまま冷却した．

焼結後の試料に対して，トルエンを用いて JIS-R2205に 準拠したアルキメデス法によりかさ密度を測定した。さら に，X線回折による相の同定，SEM による研磨面と破断面 の微細組織の観察を行った。な执，研磨面の組織観察に扣い てはナイタル液による腐食を行った。ネック直径は破断面か らSEMにより求めた。50ないし55個のネックにつき綐横 2 点の測定を行い，その平均ネック直径とした。

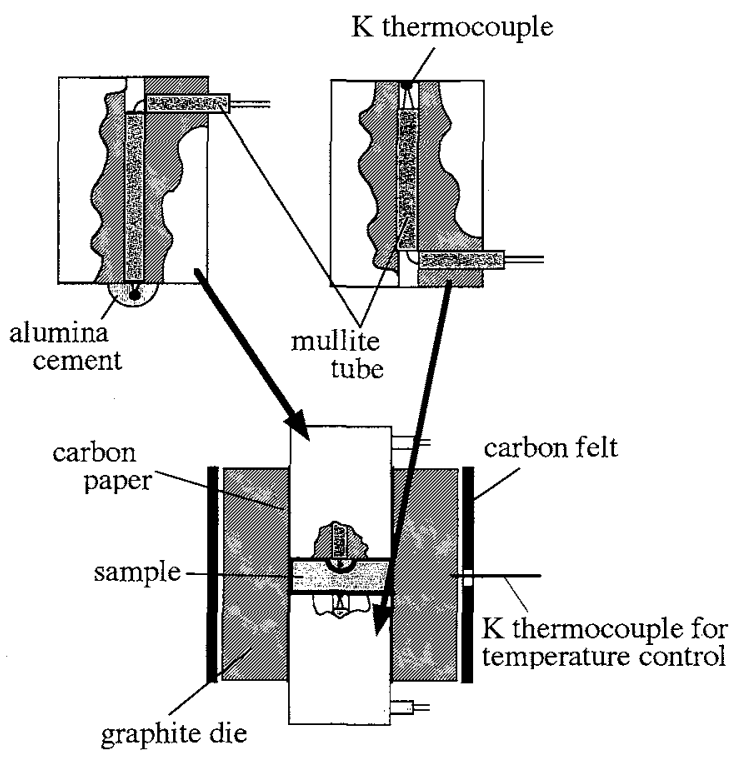

Fig. 2 Schematic drawing of the graphite die for measuring sample temperature during the pulse-current pressure sintering.

\section{III. 結果}

Fig. 3 K型内粉末の試料温度を示す，実験温度全域にわ たり，型表面温度に比べて試料/パンチ界面，試料内部の順 に温度が高い，型表面温度が $823 \mathrm{~K}$ に和いては，パンチ界 面は $850 \mathrm{~K}$ ，試料内部は $895 \mathrm{~K}$ であり，型表面温度が 1023

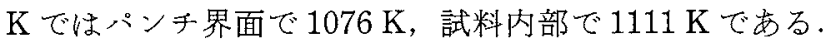
内部温度測定用パンチもしくは界面温度測定用パンチのみで 試料の温度を測定した結果は両方の温度測定用パソチを同時 に使用した場合と差は見られなかった。試料に密度 $85 \%$ の 焼結体を用いた場合，試料の内部と表面の盜度差は粉末を試 料とした場合と比較して最大で $5 \mathrm{~K}$ ほどであった。また，

Fig. 3 から，㾕結実験の型温度 $873 \mathrm{~K}$ では試料温度を 950 $\mathrm{K}$ とした。

Fig. 4 亿試料温度 $950 \mathrm{~K}$ (型表面 $873 \mathrm{~K}$ )，保持時間 1.8 $\mathrm{ks}$, 圧力 $13 \mathrm{MPa}$ で焼結した試料の研磨面 SEM 像を示す。 加圧方向に関係なく一様にネックが成長している. Fig. 4(a)K示すよらに，ネック部に亀裂や気孔は認められない。 Fig. 4(b)はネック部断面の拡大写真である。ネック表面の 曲率半径㥛めて小さい.Fig. 4(c) は粒子の接合界面を示 すが，ネック部以融解や再結晶の痕跡は観察さ机ない，粒子 同土は接合しているが，境界は互いの組織を保ったますであ る. 交たネック部近傍が著しく変形した形跡や再結晶化は観 察されない，XRDによる相同定の結果，暁結体は $\alpha$-Fe と $\mathrm{Fe}_{3} \mathrm{C}$ から成り，原料粉末で検出された残留 $\gamma-\mathrm{Fe}$ 認められ なかった。高た，型表面温度 $873 \mathrm{~K}$ ，保持時間 $1.8 \mathrm{ks}$ に扣 いても, 微量の $\mathrm{FeO}$ が存在した。

Fig. 5 に試料温度 950 K(型表面 873 K) の焼結体に打外 る破断面の SEM 像を示す．Fig. 5(a) は圧力 $13 \mathrm{MPa}$ ，保持 時間 $0 \mathrm{ks}$, Fig. 5 (b) は圧力 $34 \mathrm{MPa}$ ，保持時間 $1.8 \mathrm{ks}$ であ る.どセらの場合もネック部で破断している，本実験で最も

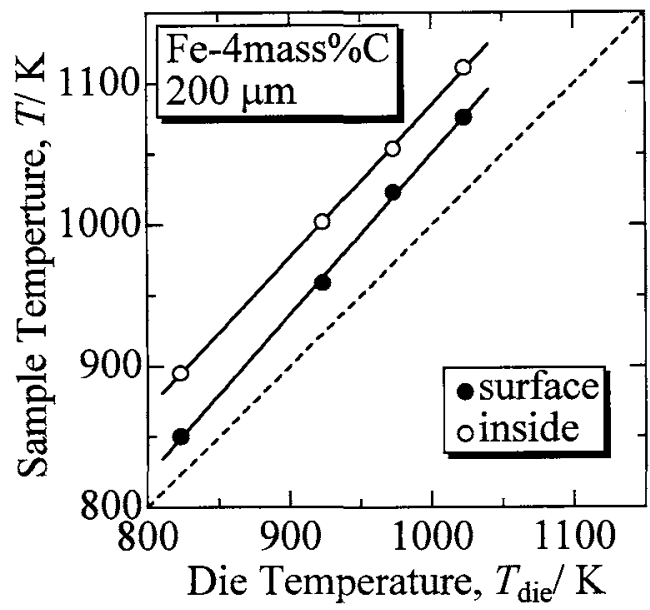

Fig. 3 Sample temperature, $T$, as a function of die temperature, $T_{\mathrm{die}}$, during the pulse-current pressure sintering with the atomized cast-iron powder 

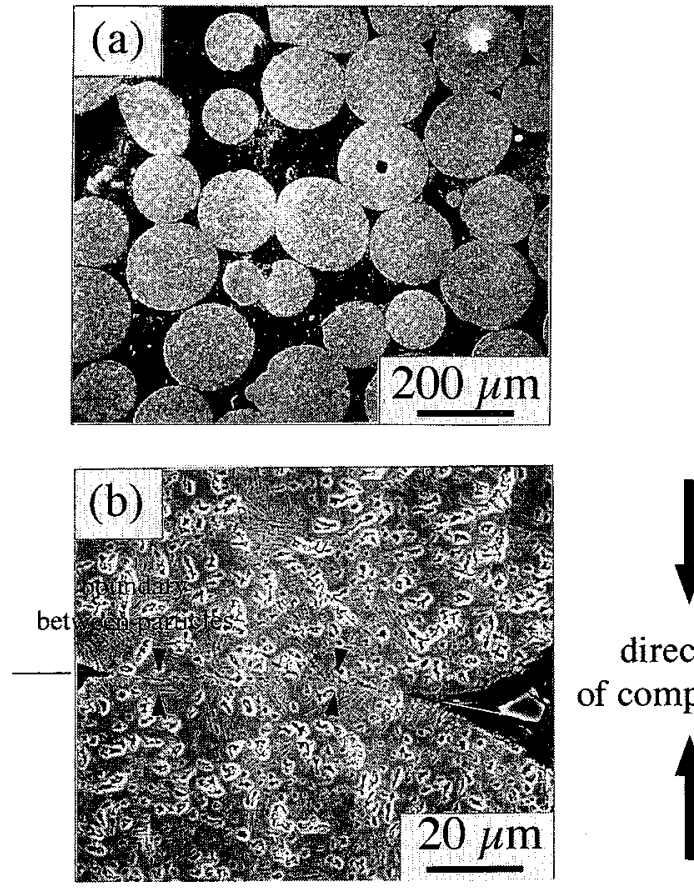

direction of compression

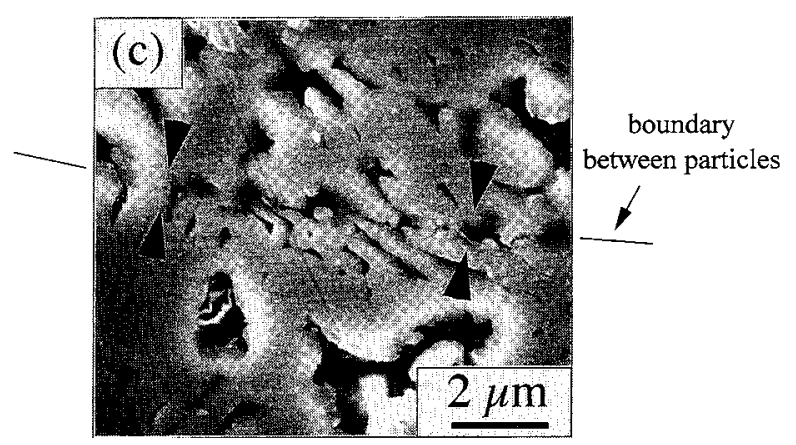

Fig. 4 SEM images of cross-section of sintered cast-iron by the pulse-current pressure sintering $\left(T=950 \mathrm{~K} \quad\left(T_{\mathrm{die}}=873\right.\right.$ $\mathrm{K}) / 13 \mathrm{MPa} / 1.8 \mathrm{ks}$. (a) cross-sectional view of the sintered body, (b) a neck area, and (c) an interface between particles.

緻密化が進行した圧力 $34 \mathrm{MPa}$ ，保持時間 $1.8 \mathrm{ks}$ の試料のネ ック平均直佳は $90 \mu \mathrm{m}$ であり，初期平均直径 $200 \mu \mathrm{m}$ の約半 分となった。この条件では，ほとんどのネックは他のネック と接触・合体を起こしていない。

Fig. 6 に試料温度 $950 \mathrm{~K}$ (型表面 $873 \mathrm{~K}$ )で燒結した鋳鉄 のかさ密度 $(\rho)$ の焼結時間 $(t)$ 依存性を示す. 圧力 $13 \mathrm{MPa}$ では密度の增加は小さいが，34 MPa では維密化が進行して いる、鋳鉄の密度は構成する相により变化するが，本実験の 試料では $\alpha-\mathrm{Fe} と \mathrm{Fe}_{3} \mathrm{C}$ から構成されているので, その理論 的な体積分率か $57.8 \mathrm{Mg} \cdot \mathrm{m}^{-3}$ とした。焼結体密度は圧力 $13 \mathrm{MPa}$ ，保持時間 $0 \mathrm{ks}$ の条件で相対密度が $67 \%$ であり，最 も緻密化が進行した圧力 $34 \mathrm{MPa} て ゙$ 保持時間 $1.8 \mathrm{ks}$ の試料 でる73\%である。したがって，焼結体密度の観点からも， 焼結段階が初期から中期に位置していることがわかる。高 た，密度変化飞対する圧力の影響が大きいことがわかる。
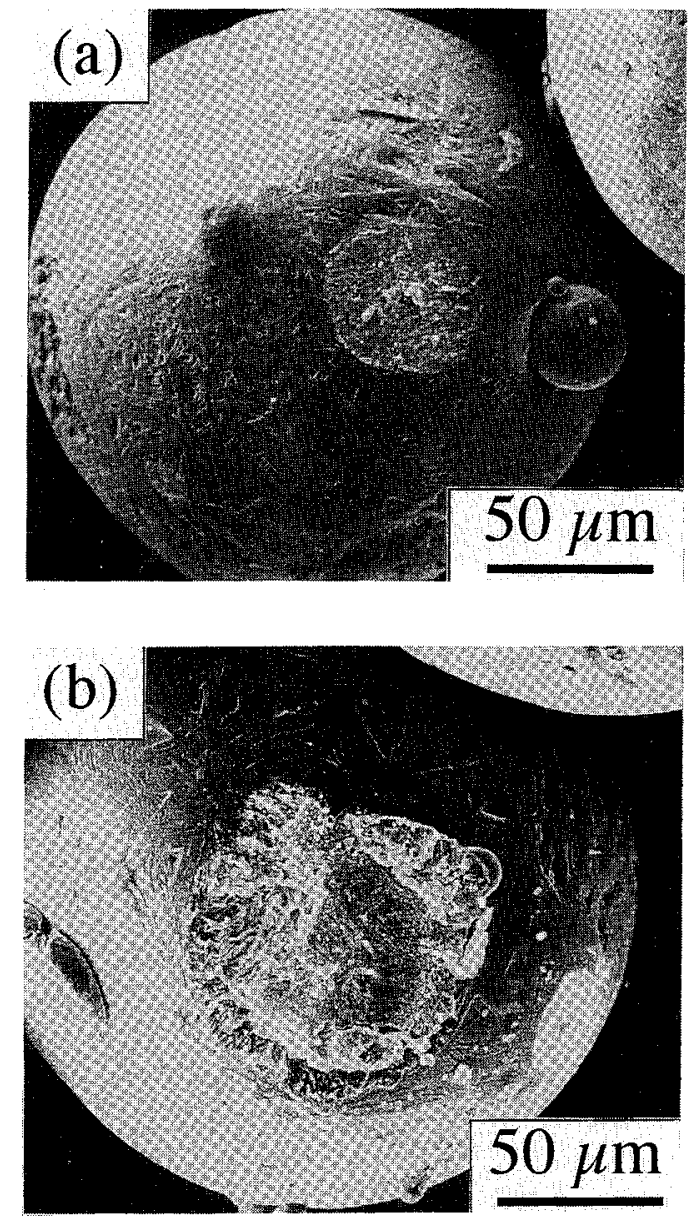

Fig. 5 Fractured neck surface of the sintered body produced by the pulse-current pressure sintering at $T=950 \mathrm{~K}\left(T_{\mathrm{die}}=873\right.$ $\mathrm{K})$. (a) applied pressure: $13 \mathrm{MPa}$, sintering time: $0 \mathrm{ks}$, and (b) applied pressure: $34 \mathrm{MPa}$, sintering time $1.8 \mathrm{ks}$.

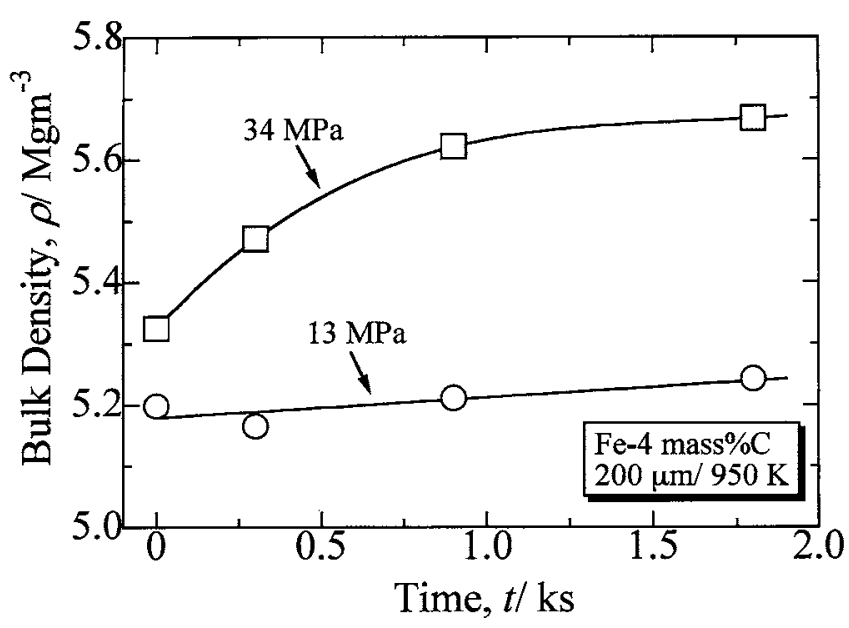

Fig. 6 Change of bulk density, $\rho$, of sintered body during the pulse-current pressure sintering process at $T=950 \mathrm{~K}\left(T_{\text {die }}\right.$ $=873 \mathrm{~K}$ ). 


\section{N. 考察}

試料の内部温度を測定した結果, 型表面温度 $873 \mathrm{~K}$ 亿抏 いては型表面温度よりも試料/パチ界面の温度は約 $30 \mathrm{~K}$, 試料内部は $70 \mathrm{~K}$ 程度高かった。李た，試料の内部温度はそ の表面よりも $40 \mathrm{~K}$ 程度高い。このことは, 鋳鉄粉末を使っ た場合は試料自身がシュール発熱しているためであると考克 られる。また，試料を相対密度 $85 \%$ の暁結体とした場合， 粉末に比べて最大で $5 \mathrm{~K}$ ほどの試料の温度低下が認められ た。この結果から，本実験での密度範囲での緻密化による温 度変化は無視でるるのと考㝋られる。

冨野らの銅を試料之した結果(9)では，型表面温度 $950 \mathrm{~K}$ で試料中央が $1130 \mathrm{~K}$ であり，その温度差は $180 \mathrm{~K}$ と，本実

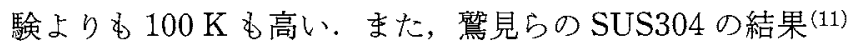
では，型表面温度 $1025 \mathrm{~K}$ で，試料中央温度が $1175 \mathrm{~K}$ とな

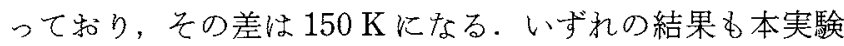
飞比較して $100 \mathrm{~K}$ 前後，高いことになる。この理由は，型 の肉厚の違いが挙げられる。本実験では型の肉厚が $7.5 \mathrm{~mm}$ であるのに対し，冨野らの型の肉厚は $20 \mathrm{~mm}$ ，䳺見らは 15 $\mathrm{mm}$ である. 彼らの型内部温度の測定結果によると, 陚料/ 型界面から $7.5 \mathrm{~mm}$ のところでは冨野らの場合が $1020 \mathrm{~K}$, 駕見らの場合は $1050 \mathrm{~K}$ となって和り，試料中央との温度差 はとれぞれ $110 \mathrm{~K}, 125 \mathrm{~K}$ となる。試料/型界面から $7.5 \mathrm{~mm}$ の温度を型表面温度として Fig. 2 から本実験での試料温度 を推定すれば，型表面温度が $1020 \mathrm{~K}$ と $1050 \mathrm{~K}$ では，それ ぞれ $1106 \mathrm{~K}$ と $1139 \mathrm{~K}$ となる。劷の温度差はそれぞれ $86 \mathrm{~K}$

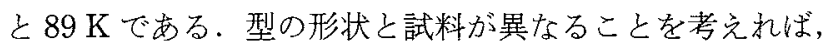
本実験での試料の温度と型表面温度との差はいずれの実験と も同程度にあるといえる。試料内部の温度と型表面の温度差 は型の寸法の影響が極めて大きいことが示唆される。 また， 本実験では銅やSUS304 亿比べて抵抗の大きい鋳鉄を用い ている. 試料の抵抗が高い場合, 相対的に型の電流が大き く, 試料の電流が小さくなるので, 試料のジュール発熱は減 少する。したがって，同じ型温度であっても，試料の抵抗の 大きいるのでは試料と型の温度差が小さくなるものと考古ら れる。

横田ら (12) は Al 合金の粉末をSPS 焼結した際にネック部 近傍の粒子表面に融解の痕跡を確認したと報告している。彼 らの実験の場合，型表面温度と合金と液相生成温度が $150 \mathrm{~K}$ 程度の差しかない，型内部の温度が型表面温度より $100 \mathrm{~K}$ 前後高いことを考光机ば，温度が燒結温度が融点に近い場合 快通電による局部的な発熱がわずかでる，部分的比融解する 可能性が女る。しかし，本実験の鋳鉄の場合，焼結温度が液 相生成温度より $470 \mathrm{~K}$ 低いので，融解は起きないと考方ら 孔る。

アトマイズ鋳鉄粉末の真空焼結(20)では, $1323 \mathrm{~K}$ から微細 構造が变化し始めたと報告されている。パルス通電加压燒結 により型表面温度 $873 \mathrm{~K}$ で焼結した試料ではネック部近傍
でる微細構造の変化が観察されないため, 少なくとも, $1323 \mathrm{~K}$ には達していないと考学られる。

Fig. 4 亿示すよらに，鋳鉄粒子は上く接合しているが，明 確な粒子の境界が観察される。粒子の接合界面で融解や再 結晶の痕跡は見られない，このことから，パルス通電加圧焼 結中にネック成長はネック部近傍での融解や蒸発により起き ているものではないと考光られる。融解や蒸発により接合し た場合，ネック表面に移動した融体や蒸気が固化した組織が 観察されなくてはならないが，本実験ではとのようなものは 確認できなかった。㐬た，粒子界面から原子が移動しネック を成長させる場合, ネック部は出発粒子と異なる組織により 形成されると考光られる。しかし，ネック部近傍に和いてる 組織は均質で㐫った。したがって，鋳鉄粒子が压力により塑 性変形したことでネックが形成したと考兄られる。亦た，ネ ック近傍で共晶組織纪認識できるよらな变形がないことか ら，ネック部近傍の温度のみが高くなり，選択的に変形した のではなく，均一な温度の下で粒子全体が塑性変形したるの と考光られる.以上の観察結果は冨野らの結果 ${ }^{(14)}$ とょく一 致している.

金属粒子のパルス通電加圧焼結によるネック成長が均一温 度下に打㚈る粒子の塑性変形であることを定量的化評価する ために，ネック成長速度を以下の粒子の塑性変形モデルから 推算する。(1)焼結はごく初期段階である。個タのネックは独 立して特り，ネック同士の接触・合体快起さない（2)粒子の 自由表面は常记球形であり，直径の変化は無視できる汪ど小 さく, $200 \mu \mathrm{m}$ で一定である。(3)ネック成長は鋳鉄粒子の定 常クリープ变形により起きる。クリープ变形速度は，指数 則：

$$
\dot{\varepsilon}=K \sigma^{n}
$$

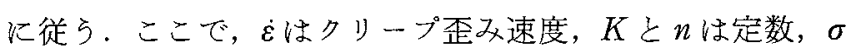
は応力を示す. 本実験では, 測定温度と微細構造が類似して いることから，Caligiuri ら (21)の 923 K と佂り 2.6 mass\% 白鋳鉄のクリープ变形速度：

$$
\dot{\varepsilon} / \mathrm{s}^{-1}=8.8 \times 10^{-11}(\sigma / \mathrm{MPa})^{3.32}
$$

を採用した。

以上の仮定をもとに粒子の塑性変形炕よるネックの成長速 度は以下のように表される。焼結の進行に伴い, Fig. 7 に 示すように，粒子が自由表面は球形を維持したま鼓状に変 形すると仮定すると，粒子の微小部分 $\mathrm{d} h$ の変形速度 $(\mathrm{d} \dot{\lambda})$ は 以下のように表される。

$$
\mathrm{d} \dot{\lambda}=\dot{\varepsilon} \mathrm{d} h=K \sigma^{n} \mathrm{~d} h=K\left(\frac{f}{\pi a^{2}}\right)^{n} \mathrm{~d} h
$$

ここで, $r$ は鋳鉄精子の半径を示す. $f$ は 1 つのック部に 印加される力であるが，組織観察の結果から加圧方向によら ず均質であると仮定し，Coble (22)が求めた。

$$
f=\frac{4 \pi r^{2} \sigma_{\mathrm{p}}}{N_{\mathrm{c}}}
$$

に従うすのとした。ここで $\sigma_{\mathrm{p}}$ はパンチ炕よる印加圧力， $N_{\mathrm{o}}$ は平均配位数を示す。 Jernot ら (23) 怯粉末成形体の平均配位 


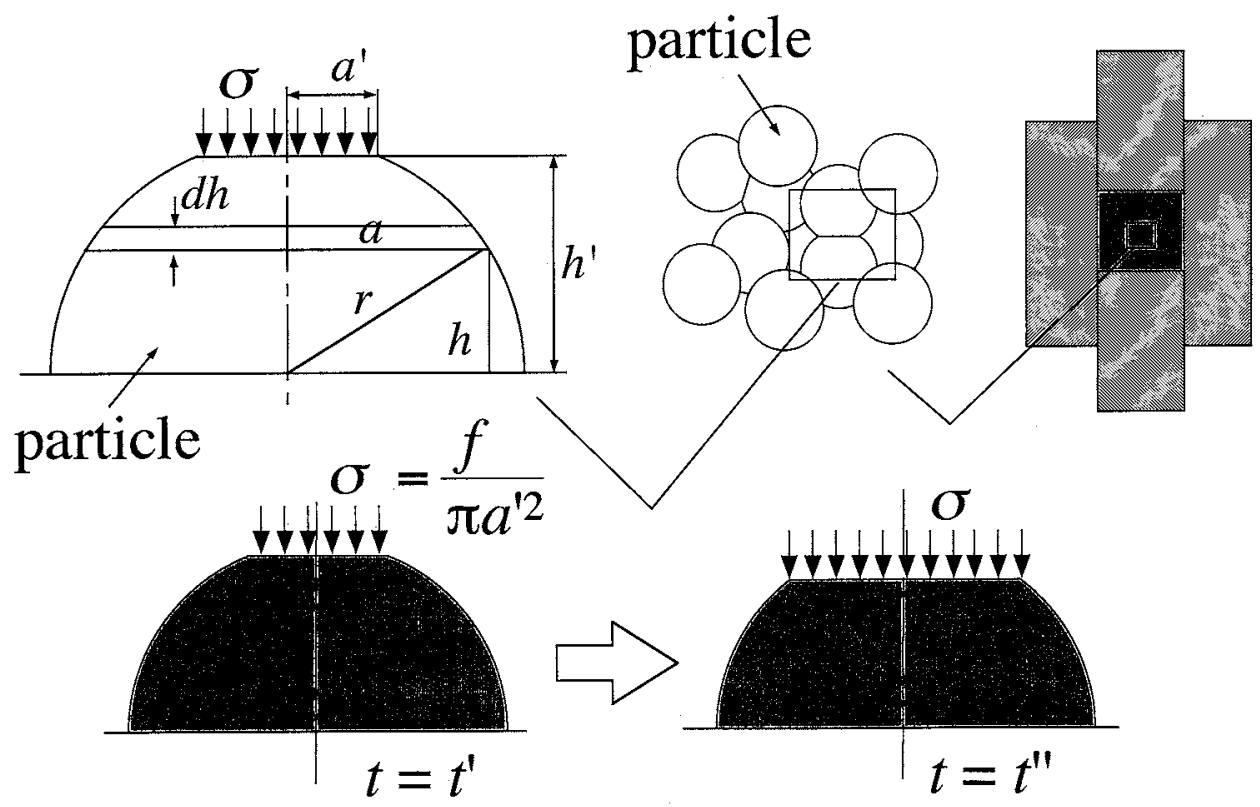

Fig. 7 Schematic illustration on a model of the initial stage of sintering governed by plastic deformation.
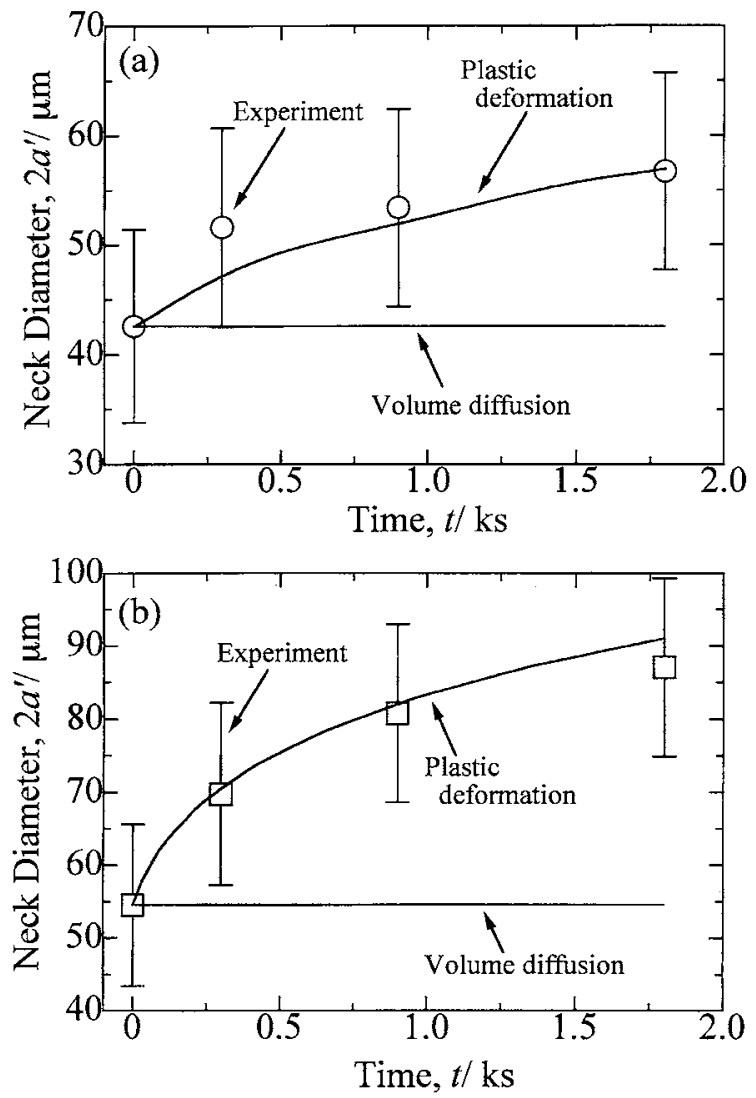

Fig. 8 Change of neck diameter, $2 a^{\prime}$, during the pulse-current pressure sintering of atomized cast-iron at $T=950 \mathrm{~K}$ ( $T_{\text {die }}$ $=873 \mathrm{~K}$ ). (a) applied pressure: $13 \mathrm{MPa}$, and (b) applied pressure: $34 \mathrm{MPa}$.
数と密度の関係を調査した．Fig. 6 の結果から，粉末粒子が 点接触した状態では相対密度が和よそ60\%程度であると考 完られるので, 彼らの結果から平均配位数は 6 とした。

幾何学的に $a^{2}=r^{2}-h^{2}$ であるから, 式 $(3)$ は

$$
\mathrm{d} \dot{\lambda}=K\left(\frac{f}{\pi\left(r^{2}-h^{2}\right)}\right)^{n} \mathrm{~d} h
$$

となる。したがって，粒子全体の変形速度は式 (5)を $h=0$ から $h^{\prime}$ で積分することにより得られる。

$$
\dot{\lambda}=K \int_{0}^{h^{\prime}}\left(\frac{f}{\pi\left(r^{2}-h^{2}\right)}\right)^{n} \mathrm{~d} h
$$

そして, 保持開始 $(t=0)$ のとき測定したネック直径から $h^{\prime}$ の值を計算し，式(6)で求められた $\dot{\lambda} t=0 か ら t=t^{\prime}$ まで積分することにより，t=t'での $h^{\prime}$ を求めることができ る.

$$
h^{\prime}=h_{i=0}^{\prime}-\int_{0}^{t^{\prime}} \dot{\lambda} \mathrm{d} t
$$

ネック直径 $2 a^{\prime}$ は，式 $(7)$ から求めた $h^{\prime} を も と に$ 時間の関 数として求めることができる.

Fig. 8 は試料盜度 950 K(型表面 $873 \mathrm{~K}$ ) でパルス通電加 圧焼結されたアトマイズ鋳鉄粒子のネック直径 $\left(2 a^{\prime}\right)$ の時間

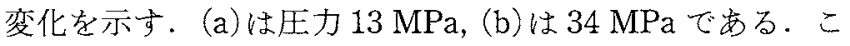
こで $t=0 \mathrm{ks}$ 保持開始を示す。図中の記号はネック直径の 測定結果の平均值で，エラーバーは標準偏差を示す。ネック 直径は時間とともに增加している。 また，圧力 $13 \mathrm{MP} に$

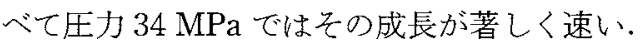

塑性変形によるネック成長のモデル計算結果は平均ネック 直径とよく一致している。このことは本実験で適用したもデ ルが妥当であることを示唆している。李た，Fig. 8 には Coble と Ellis に上る加厈時の体積拡散によるネック成長モ 
デル(24) :

$$
\frac{\mathrm{d} a^{\prime}}{\mathrm{d} t}=\frac{16}{\pi} \frac{r D_{\mathrm{V}} f \Omega}{x^{4} k_{\mathrm{B}} T}
$$

をるとに, 保持時間 $t=0$ に抢子るネック半径 $a_{0}$ を初期条件 として積分した式：

$$
\left(\frac{a^{\prime}-a_{0}^{\prime}}{r}\right)^{5}=\frac{80}{\pi} \frac{D_{\mathrm{V}} f \Omega}{r^{4} k_{\mathrm{B}} T} t
$$

を用いて体積拉散についても検討した。ここで， $\Omega$ は原子 体積 $\left(1.2 \times 10^{-29} \mathrm{~m}^{3}\right), k_{\mathrm{B}}$ はボルッマン定数を示す。体積拡 散係数 $\left(D_{\mathrm{v}}\right)$ は純粋な $\alpha$ - $\mathrm{Fe}$ の值 $\left(4 \times 10^{-18} \mathrm{~m}^{2} \mathrm{~s}^{-1}\right)$ (25)を用い た. 白鋳鉄中では $\alpha$ - Fe 相が最も应散が速いと考光られる。 しかし， $\mathrm{Fe}_{3} \mathrm{C}$ にら搪散面積は減少すると考叴れば，純粋 な $\alpha \mathrm{Fe} の D_{\mathrm{v}}$ を用いた計算結果は大さめに見積もられたネ ック直径といえる. Fig. 8 亿示するうに，体積拡散ではネッ クが臣とんど成長しないことがわかる。したがって，白鋳鉄 のパルス通電加圧焼結では，通常のホットプレス(22) と同様 に白鋳鉄粒子の塑性変形により進行すると考㝋られる。

パルス通電加圧尭結では， $\mathrm{Al}$ や $\mathrm{Ti}$ のような強固な酸化皮 膜を有する金属粉末に执いても容易に焼結が進行すると報告 されている(1)(12). その場合，松木ら(8)が述べているように， パルス通電加圧焼結の開始時に，放電やネックでの局部発熱 に上り皮膜が破壞され，ホックの形成を促進する可能性があ る.しかし，本実験の結果から，パルス通電加圧焼結に扣け る初期段階のネック成長過程は，比較的粒径が大きい全属粗 粉末の場合, 均一温度のもとで粒子が塑性変形してネックが 成長すると考它られる。

\section{V. 結 論}

試料内部の温度を測定して, 粒径 $200 \mu \mathrm{m}$ の鋳鉄粉木のパ ルス通電加王焼結を行い，そのネック成長過程を検討した。 外形 $30 \mathrm{~mm}$, 内径 $15.4 \mathrm{~mm}$ の黒鉛型を使った場合, 型表面 温度 $873 \mathrm{~K}$ において，試料内部の温度は型表面より $70 \mathrm{~K}$ ほ ど高く，試料/パンチ界面より，40 K ほど高かった。

融解や再結晶の痕跡は確認されず，ネック表面の曲率半径 が非常に小さかったことから，アトマイズ鋳鉄粒子のパルス 通電加圧焼結に拟坊るック成長は塑性変形によると考兄, 均一温度の下，粒子全体が塑性変形してネックが成長する焼 結モデルを仮定した。このモデルほより計算したネック成長 速度と実験結果がょく一致しており，パルス通電加圧焼結に よるアトマイズ鋳鉄粉末のネック成長が粉末粒子の塑性変形 で進行していることがわかった。京た，本実験では，従来， パルス通電加圧焼結の焼結機構として説明されているような
ネック部近傍の放電による融解や気化による急速な粒子接合 やネック部の局部的なジュール加熱による急速なネック成長 が扣きていないことを指摘した。

本研究の結果から，粒径の大きい鋳鉄粉末のパルス通電加 圧焼結に和いては通常のホットプレスと同様に粒子全体の塑 性変形がネック成長の支配過程であることがわかった，パ ス通電加压焼結の焼結挙動を検討する場合，試料内部の温度 を十分に把握し，印加される圧力による塑性変形の影響を考 慮することが非常に重要である.

\section{文献}

(1) M. Tokita: J. Soc. Powder Technol. Jpn., 30(1993), 790-804.

(2) O. Yanagisawa, T. Hatayama and K. Matsuki: Materia Jpn., 33 (1994), 1489-1496.

(3) M. Oomori and T. Hirai: New Ceramics, 1994 (7), 27-31.

(4) K. Ishizaki and M. Nanko: New Ceramics, 1994 (7), 47-50.

(5) H. Oonishi, Y. Ikarashi, M. Nanko, A. Kondo, T. Nagai and K. Ishizaki: New Materials, 7(1996), 34-37.

(6) M. Nanko, H. Onishi and K. Ishizaki: Ceramic Industry, 145 (1996), 31-37.

(7) N. Murayama: Ceram. Jpn., 32(1997), 445-449.

(8) K. Matsuki, T. Hatayama and O. Yanagisawa: J. Jpn. Inst. Metals, 59(1995), 740-745.

(9) H. Tomino, H. Watanabe and Y. Kondo: J. Jpn. Powder Powder Metal., 44(1997), 974-979.

(10) T. Abe, S. Sumi, H. Hasimoto and T. Kuriyama: Materia Jpn., 35(1996), 804-809.

(11) S. Sumi, Y. Mizutani and M. Yoneya: J. Jpn. Powder Powder Metal., 45(1998), 153-157.

(12) M. Yokota, M. Nose and T. Nagase: Proc. 1997 Fall Meeting of Jpn. Powder Powder Metal., (1997), p. 186.

(13) T. Nagae, M. Yokota and M. Nose: J. Jpn. Powder Powder Metal., 44(1997), 945-950.

(14) H. Tomino, Y. Kondo, M. Katumura and T. Tojo: J. Jpn. Powder Powder Metal., 45(1998), 703-708.

(15) H. Kimura and S. Kobayashi: J. Jpn Inst. Metal., 58(1994), 201-207.

(16) H. Onishi, Y. Kondo, S. Yamamoto, A. Tsukuda and K. Ishizaki: J. Ceram. Soc. Jpn., 104(1996), 610-613.

(17) Y. Hagiuda, K. Karikomi and T. Nakagawa: J. Soc. Precise Eng., 53(1987), 1562-1568.

(18) H. Tomino, Y. Kondo, M. Katumura and T. Tojo: J. Jpn. Powder Powder Metal., 45(1998), 709-714.

(19) H. Tomino, Y. Kondo, M. Katumura and T. Tojo: J. Jpn. Powder Powder Metal., 45(1998), 715-720.

(20) H. Tomino, Y. Kondo and M. Katumura: J. Jpn. Powder Powder Metal., 44(1997), 590-595.

(21) R. D. Caliguri, R. T. Whalen and O. D. Sherby: Intl. J. Powder Metall. Powder Tech., 12(1976), 9-16.

(22) R. L. Coble: J. Appl. Phys., 41 (1970), 4798-4807.

(23) J. P. Jernot, M. Coster and J. L. Chermant: Powder Technol., 30 (1981), 21-29

(24) R. L. Coble and J. S. Ellis: J. Am. Ceram. Soc., 46(1963), 438-441.

(25) R. J. Borg and C. E. Birchenall: Trans. Metal. Soc. AIME, 218(1960), 980-984. 